\title{
Analyses of the Velebit Mountain Ridge Crests
}

\author{
Sanja Faivre
}

\begin{abstract}
Generally the ridge crests spread in the dinaridic direction that is NW-SE what is mainly the characteristic of the older tectonic phase. The turn point in morphogenesis of the External Dinarides and thus of the Velebit Mt. occurs with the change in the shift of the Adriatic microplate toward N and NNW what is reflected on the orientation and morphology of the ridge crests as well as on the other relief form. The analyses of ridge crests are based on three main criteria: the analysis of orientation, length and the analysis of relatively homogeneous zones.
\end{abstract}

Key words: ridge crests, structural geomorphology, Velebit Mt., Dinarides

\section{Analiza grebena gorskog uzvišenja Velebita}

Generalno, grebeni gorskog uzvišenja Velebita pokazuju dinaridski pravac pružanja SZ-JI koji je prvenstveno odraz starijih tektonskih obilježja. Ključna promjena u oblikovanju vanjskih Dinarida pa tako i Velebita dogodila se promjenom kretanja Jadranske mikroploče prema S i SSZ što se odrazilo na orijentaciju i oblik grebena kao i na ostale reljefne oblike. Analiza grebena temelji se na tri kriterija: analizi orijentacije, dužini i analizi pojedinih uvjetno homogenih zona.

Ključne riječi: grebeni, strukturna geomorfologija, Velebit, Dinaridi

\section{INTRODUCTION}

The relation between geological structure and landscape has always been an important subject in geomorphology (Rovereto, 1923 ; Gerasimov, 1946 ; Birot, 1958 ; Twidle, 1971), but, in the last few decades, the interest in this subject has strongly increased. Many researchers have focused their attention on the influence of active tectonism on landform development and the terms «morphotectonics» and «tectonic geomorphology» have appeared in the literature. The renewed interest is especially the consequence of the plate tectonic theory and the development of remote sensing. This has come 30 years since the plate tectonic revolution in geology began, with its profound implications for the global 
geomorphology. The aims of modern morphotectonic studies comprise the statement of both concepts and methods as well as the practical application (Ollier, 1981 ; Morisawa and Hack, ed. 1985).

In the structuro-geomorphological analysis we need relief forms which origin is directly related to geological structures and tectonic movements. In the last three decades the morphological evidence of tectonics was often examined from the drainage network (e.g. Buonasorte et al. 1991 ; Centamore et al. 1996 . Coltorti et al. 1996, Belisario et al. 1997, Rebeiro-Hargrave 1997, Boni et al. 1997). Consequently, the relation between tectonics and surface drainage is well established. However, the ridges have not been much investigated.

The Velebit mountain spreads over $2274 \mathrm{~km}^{2}$, with the length of $145 \mathrm{~km}$ and maximum height of $1757 \mathrm{~m}$ at Vaganski vrh. The well preserved karst topography is characterized by prominent ridge and valley structures which are mainly tectonically predisposed. Therefore, in this paper, ridges will be analysed in a more general way than usually. That means, not one by one, but their shape, position and orientation will be studied on the whole studied area, in order to discover what kind of deformation reflects ridge crests. As a turning point in the morphogenesis of the Outer Dinarides mountain range which occurs with the shift of the Adriatic microplate northwards (Anderson \& Jackson, 1987), we try to determine the main original outline analysing the present day features and particularly the influence of newly appeared stress field on the landforms reshaping.

\section{TECTONIC SETTING}

At a regional scale the Velebit mountain range represents a part of the Dinarides, more precisely, a part of the Dinaric (Herak, 1986) which overthrusts the zone of the Adriatic. The Velebit mountain range is characterised by anticlinal folding and high degree fracturing. The upright, oblique and overturned folds can be recognised. In different parts of the Velebit mountain range they differ in strike, in their inter relations and in the degree of fracturing. So in the structural sense three major zones can be distinguished: north Velebit with Senjsko bilo, central and south Velebit. These three zones are bordered by fault zones that have their reflection in the relief. The positions of axes of gravimetrical maximum mark the principal structural relations, sinking of rock masses $10 \mathrm{~km}$ below the surface and overthrusting below the surface (Prelogović, 1989, Prelogović, 1995, Prelogović et al. 1999, Prelogović et al. 2004).

The faults represent a major characteristic of the structural unit. The most important one is the fault of Velebit ( $\mathrm{N}^{\circ} 1$ at Fig. 1). It is an overthrusted reverse fault with an overturn to the SW and S. The whole Velebit fault zone situated on the littoral side of the mountain is characterised by faults of the same type. Thrusting occurred on those shallow landwarddipping faults (Anderson and Jackson, 1987). The inland faults are of relatively strong inclination characterised by frequent variations. Some parts of the faults are reverse with overturn to the $\mathrm{N}$ and NE. Recently the regional faults have been successively reactivated as right lateral strike-slip faults. The most important faults are those which determine the three major parts of the Velebit mountain range. 


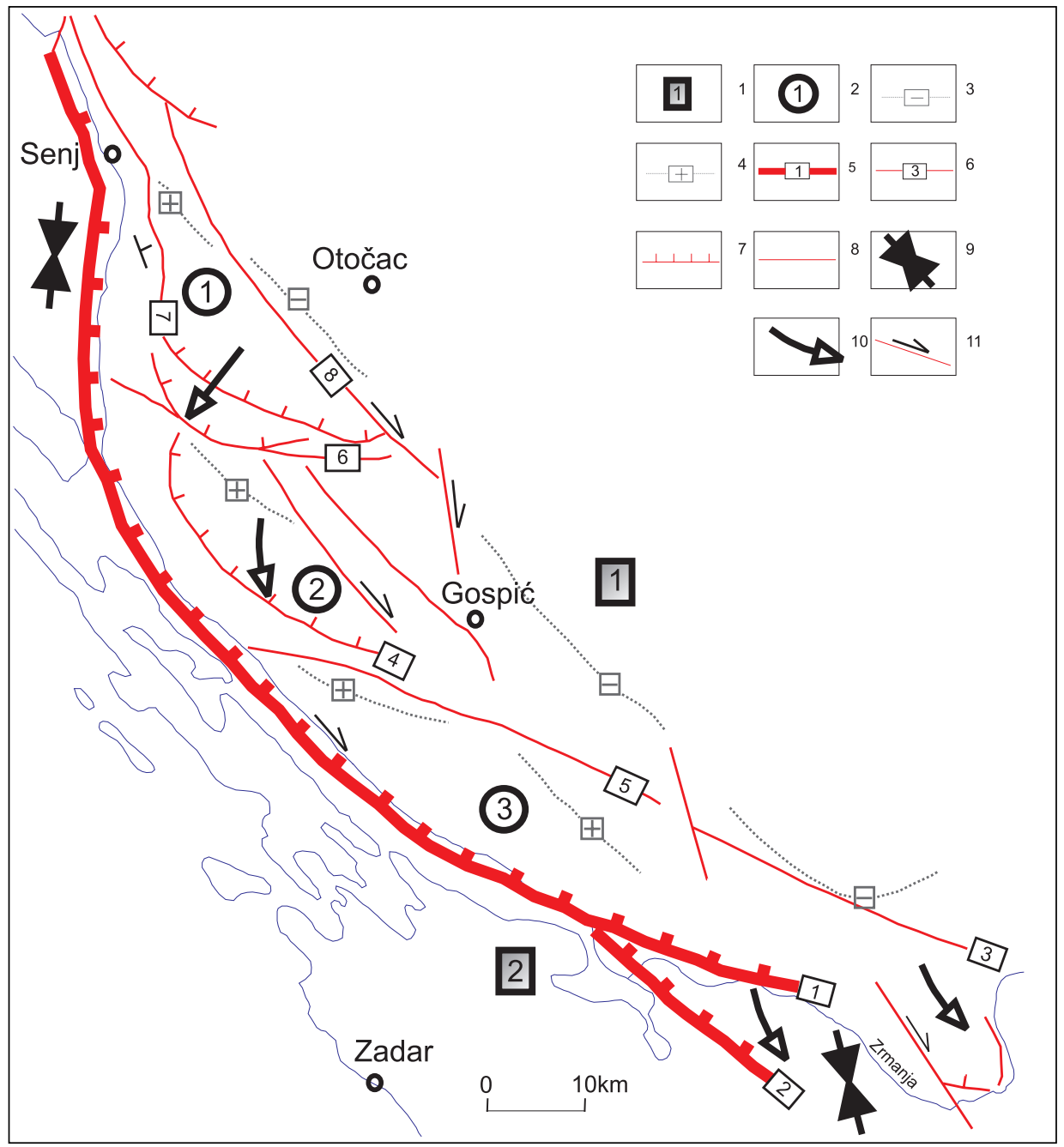

Fig.1 Structural map of the Velebit mountain range (Prelogović, 1995)

Sl.1. Strukturna karta Velebita (Prelogović, 1995.)

Geological structures:

1. Regional structures of Dinarides: (1) Adriatic,

(2) Dinaric;

2. Main parts of the structural unit of Velebit:

(1) north, (2) central (3) south;

3. Axes of minimal gravimetrical anomalies (they represent a zone of the greatest subsidence of rock masses in depth;

4. Axes of maximal gravimetric anomalies (they represent the position of rock masses of great density near the surface;
Faults:

5. Regional faults: (1) fault of Velebit, (2) fault Obrovac-Drniš-Klis

6. Faults which border main structural units of Velebit: (3) fault of Lika, (4) fault of Brušani, (5) fault of Oštarije, (6) Bakovac fault, (7) Senj fault and (8) Senjsko bilo fault

7. Reverse faults

8. Faults without defined character

9. Regional stress

10. Sense of movements of structures at the surface

11. Faults with horizontal (slip) component of tectonic movement. 
Geološke strukture:

1. Regionalne strukturne zone Dinarida: (1) Adrijatik, (2) Dinarik;

2. Glavni dijelovi strukturne jedinice Velebit: (1) sjeverni, (2) srednji (3) južni;

3. Osi minimuma gravimetrijskih anomalija koje označuju zonu najvećeg spuštanja masa stijena $u$ dubinu;

4. Osi maksimuma gravimetrijskih anomalija koje znače položaje masa stijene veće gustoće blizu površine surface;
Rasjedi:

5. Regionalni rasjedi: (1) velebitski rasjed, (2) rasjed Obrovac-Drniš-Klis

6. Granični rasjedi glavnim dijelovima strukturne jedinice Velebita: (3) lički rasjed, (4) brušanski rasjed, (5) oštarijski rasjed, (6) bakovački rasjed, (7) senjski rasjed (8) rasjed Senjskog bila

7. Reversni rasjed

8. Rasjedi bez sigurno definiranog karaktera

9. Regionalni stres

10. Smjer pomaka struktura na površini

11. Rasjedi s horizontalnom komponentom pomaka

Due to the tectonic movements the space opening can appear between faults. As a consequence of those processes the formation of the deep valleys (e.g. Bakovac, Krasno, Brušani), the canyons (Paklenica) or the poljes (e.g. Lika, Gacka) occurred (Prelogović, 1995, Bognar, 2006).

Generally, the structures of Dinaric and Adriatic areas are characterized by inverse and thrust relations. They are the consequence of the gradual movements of the Adriatic microplate and the deformation of the Earth's crust in the narrow zone of the European plate. Major features can be coherently interpreted as consequences of a succession of shortening mechanisms and block readjustments, driven by convergence between Africa and Eurasia.

It is known that the regional stress approximately SW-NE in orientation, formed the structures of Velebit. The recent Quaternary period is characterised by reorganisation of the structure of Velebit by refolding and new faulting with a stress approximately N-S (Prelogović, 1995). This change in the stress orientation is the consequence of the change in motion of the Adriatic plate from the NE to the NNW direction (McKenzie, 1972; Anderson \& Jackson 1987). The consequence is the accentuated compression or the rotation of structures, unfavourably oriented to the new stress (e.g., parts of north Velebit and the extreme southern part of south Velebit). That means, that in north and central Velebit the movements of structures occurred more to the SW and S, while in south Velebit more to the SE (Prelogović, 1995, Prelogović et al. 2004).

\section{ANALYSES OF A RIDGE CRESTS ORIENTATION}

The position and orientation of ridge crests are analysed trying to discern what kinds of deformations they reveal. All ridge crests (the highest part of any projection on the summit ridge of a mountain) were extracted from the $1: 25000$ maps. The measurement of their orientations and lengths was done from $1: 50000$ scale maps. Thus, the elementary database was constituted. The orientations and lengths of lines and the line segments, which represent ridge crests, are measured. The ridges of the Velebit mountain range very often represent arc-shaped convex axes or sinusoidal axes. In order to define the orientation of the curved ridge crests, an approximation by a set of short strait lines was done. The 
orientation and lengths of 18603 line segments were measured. Little ridges were also taken into consideration. The smallest ones represent $25 \mathrm{~m}$ in the field. The biggest one goes to $5,3 \mathrm{~km}$ on the north Velebit (the escarpment of Krasno polje - Nadžak bilo). The second one follows on the south Velebit with $3,8 \mathrm{~km}$ (Rizvanuša) and with $3,1 \mathrm{~km}$ on the central Velebit (Fig. 2).

At first sight it is obvious that the dominant orientation of ridges is NW-SE. It is the Dinaridic direction of mountain ridge axis, well expressed on the rose diagram (Fig. $3 \mathrm{~A}$ ). The greatest number of ridges fined themselves in the NW-SE quadrant. Consequently, the first maximum is around $145^{\circ}$ and the second at $125^{\circ}$ (trigonometric direction of measurement). It is particularly interesting that another peak appear around $15^{\circ}$ (Fig. 3 B).

\section{The use of the Projection method}

In order to pass from the simple frequency distribution to the deformation analysis, the second parameter must be taken into account - the length. Those two parameters allow one the use of the projection method (Panozzo, 1984). This method was previously successfully applied to the analysis of dolines (Faivre, 1999, Faivre \& Reiffsteck, 1999a, 1999b, Faivre \& Reiffsteck, 2002).

The basic operation of the proposed strain analysis, called the projection method, is to project sets of straight lines or line segments on the $\mathrm{x}$-axes while they rotate through an angle of $180^{\circ}$. From the projection function $\mathrm{A}(\alpha)$ (total length of projection versus angle of rotation) the axis of the two-dimensional finite strain ellipse and its orientation is derived with respect to a reference $x y$ co-ordinate system. The method is sensitive to the orientation of lines, but not to their position in the x-y plane (Panozzo, 1984).

\section{The Velebit Mountain - the whole data set}

The first analysis is the most general one and takes into account the whole data set. The obtained direction of maximum strain is $135^{\circ}$, that is $315^{\circ} \mathrm{N}$. The consistency between deformation and stress can not be checked in a simple way, because a realistic account of the regional situation is in most cases complicated due to the irregularities in stress distribution, complex boundary conditions, multiple displacements and the structural diversity (unhomogeneity) related to the variable rheological properties of the crust and to the presence of planes of weaknesses. Therefore, the regional maximum stress direction is just approximated to $45^{\circ}\left(45^{\circ} \mathrm{N}\right)$ (Tab. 1). This may correspond to the ancient stress, primarily produced by the NE movement of the Adriatic microplate. Another important problem of this reconstruction is that the Velebit mountain was not at the same place as it is today, therefore the calculated orientations must be regarded only relatively.

Tab.1 Results of the projection method analysis

Tab. 1. Rezultati analize dobiveni metodom projekcija

\begin{tabular}{|c|c|c|c|c|c|c|c|c|}
\hline Zone & $\begin{array}{c}\mathbf{N}^{\circ} \text { of } \\
\text { measurements }\end{array}$ & $\alpha$ max & $\alpha$ min & $\mathbf{1 8 0}^{\circ}-\alpha \mathbf{m a x}$ & $\mathbf{9 0}^{\circ}-\alpha \mathbf{m i n}$ & $\mathbf{a} / \mathbf{b}$ & RESULTS & North \\
\hline Velebit & 18603 & $45^{\circ}$ & $135^{\circ}$ & $135^{\circ}$ & $135^{\circ}$ & 1.29 & $\mathbf{1 3 5}^{\circ}$ & $\mathbf{3 1 5}^{\circ}$ \\
\hline
\end{tabular}




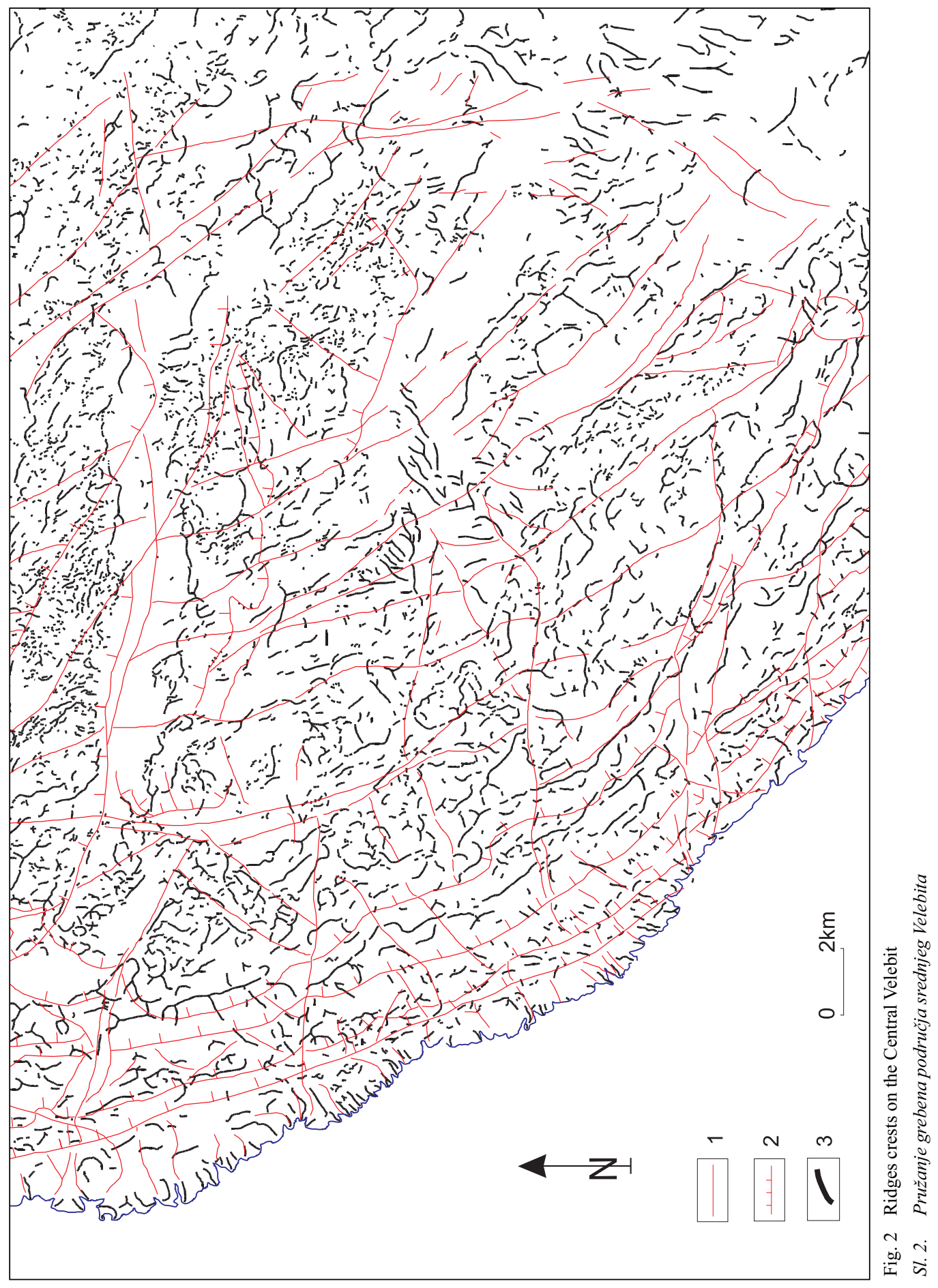




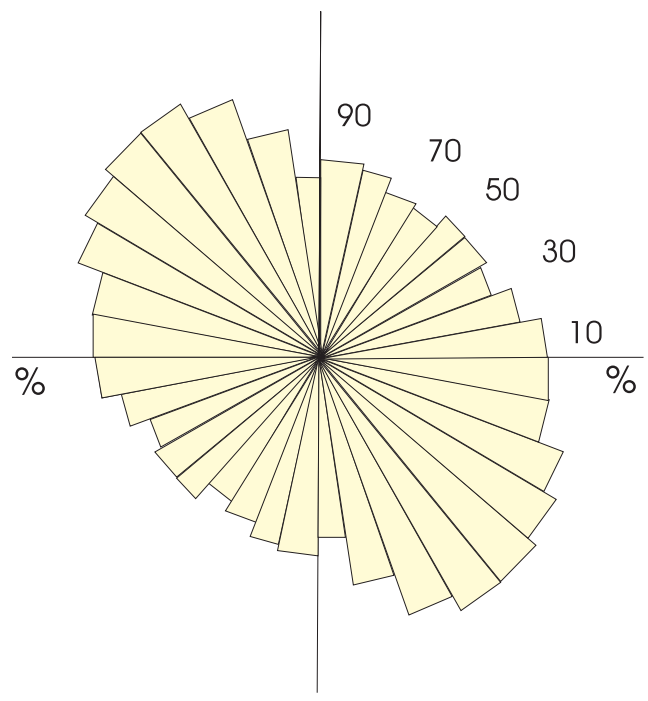

Frequency of ridges orientations

A)

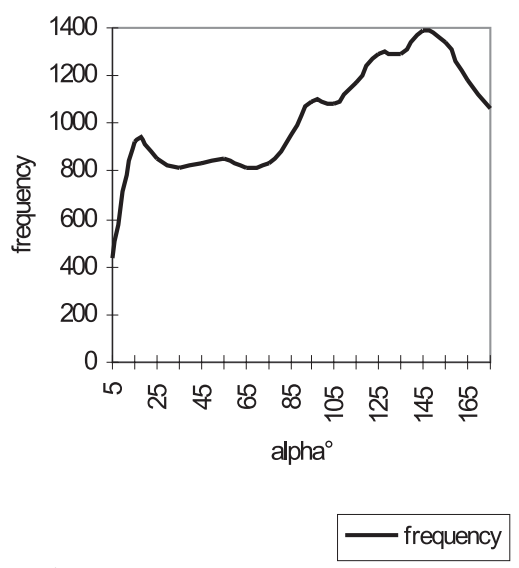

Fig. 3 A) Rose diagram of the ridges orientations

B) Frequency of ridges orientation on the Velebit mountain range (trigonometric direction of measurement)

Sl. 3. A) Ruža dijagram orijentacije grebena

B) Frekvencija orijentacije grebena Velebita (trigonometrijski pravac pružanja)

\section{Ridge analysis by three main structural units}

Afterwards, the Velebit mountain was analysed according to its three main structural parts. The orientation of the maximum strain calculated on ridges varies continuously from the north to the south. The orientation on the north Velebit is $125^{\circ}$, on the central Velebit $135^{\circ}$, and that of the south Velebit $145^{\circ}$ (Fig. 4). The gradual change in the strain is clear. As the studied zone curves to the south, the ridges are more and more inclined to the west.

Tab. 2 Results of the strain directions calculated by Projection method on the three main parts of the Velebit Mountain range

Tab. 2. Pravci deformacija izračunati s pomoću metode projekcija na pojedinim dijelovima Velebita

\begin{tabular}{|c|c|c|c|c|c|c|c|c|}
\hline $\begin{array}{c}\text { Main } \\
\text { structural } \\
\text { units }\end{array}$ & $\begin{array}{c}\mathrm{N}^{\circ} \text { of } \\
\text { measurements }\end{array}$ & $\begin{array}{c}\alpha \\
\max \end{array}$ & $\begin{array}{c}\alpha \\
\min \end{array}$ & $180^{\circ}-\alpha \mathrm{max}$ & $\begin{array}{c}90^{\circ} \\
-\alpha \min \end{array}$ & $\mathrm{a} / \mathrm{b}$ & $\begin{array}{c}\text { strain } \\
\text { RESULTS } \\
\text { trigonometrical }\end{array}$ & $\begin{array}{c}\text { strain } \\
\text { RESULTS } \\
\mathrm{N}\end{array}$ \\
\hline North Velebit & 4495 & $55^{\circ}$ & $145^{\circ}$ & $125^{\circ}$ & $125^{\circ}$ & 1.36 & $125^{\circ}$ & $325^{\circ}$ \\
\hline $\begin{array}{c}\text { Central } \\
\text { Velebit }\end{array}$ & 5293 & $45^{\circ}$ & $135^{\circ}$ & $135^{\circ}$ & $135^{\circ}$ & 1.34 & $135^{\circ}$ & $315^{\circ}$ \\
\hline South Velebit & 8808 & $45^{\circ}$ & $125^{\circ}$ & $135^{\circ}$ & $145^{\circ}$ & 1.25 & $145^{\circ}$ & $305^{\circ}$ \\
\hline
\end{tabular}




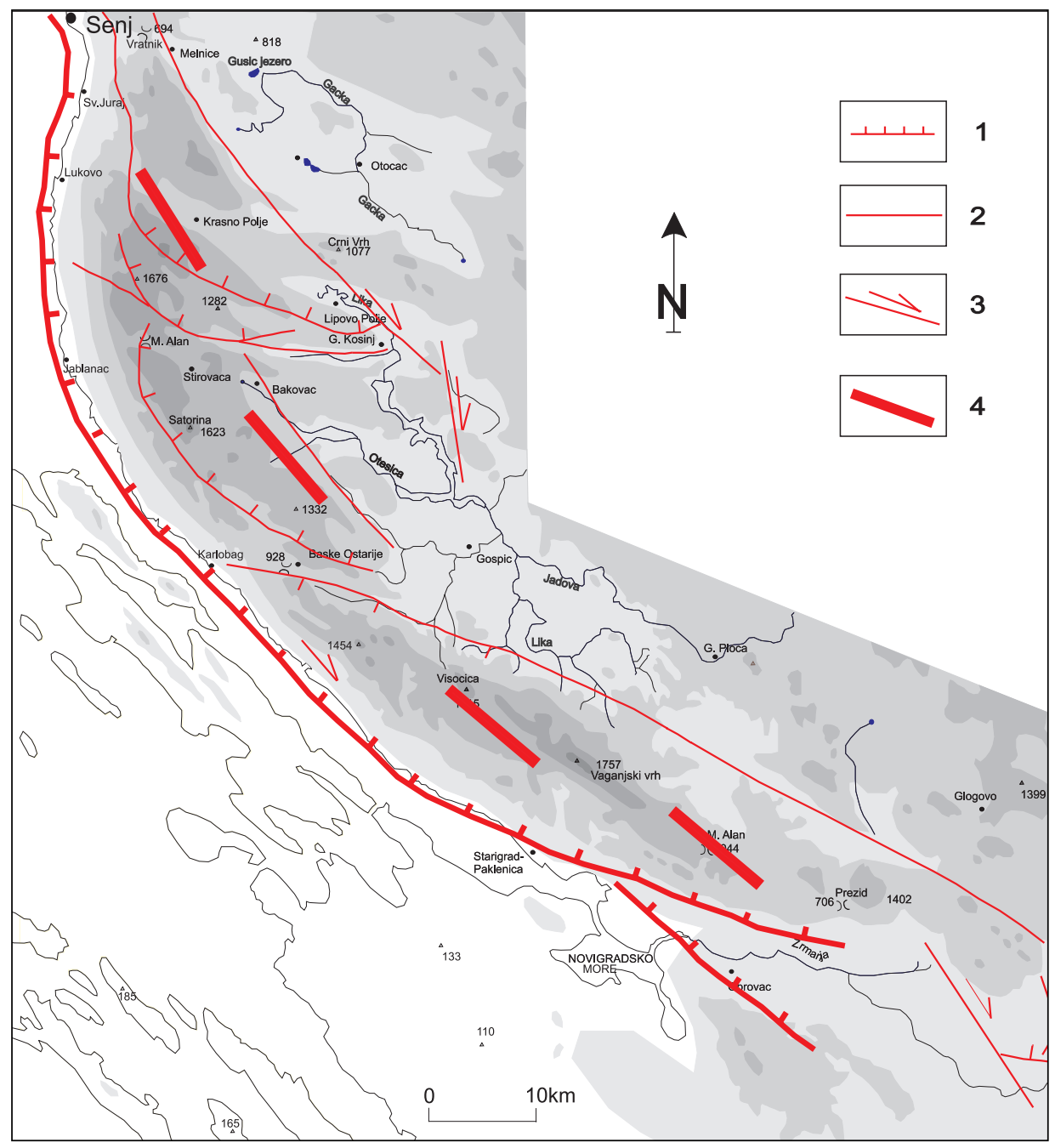

Fig. 4 Ancient maximum strain direction deduced from the ridge analyses 1 - inverse fault, 2 - normal fault, 3 - strike-slip fault, 4 - stress orientation

Sl. 4. Stariji pravac maksimalne deformacije dobiven analizom orijentacije grebena 1 - reversni rasjed, 2 - normalni rasjed, 3 - rasjed s horizontalnim pomakom, 4-orijentacija stresa

The data about the older tectonically active period are very straitened. Consequently, it is difficult to corroborate the obtained results. From the four locations of the in situ measurement (Prelogović et al. 1998; and Prelogović personal communication) it is clear that the ancient stress (as well as the recent one) shows a great local variations. Generally, the change in orientations from the NE to the NW quadrant can be clearly observed. 
Tab. 3 In situ measurements of the maximum stress direction in the ancient period (Prelogović et. al. 1998; and Prelogović personal communication)

Tab. 3. In situ mjerenja orijentacije maksimalnog stresa u starijem periodu (Prelogović et. al. 1998; and Prelogović, usmeno priopćenje)

\begin{tabular}{|l|c|c|c|c|}
\hline Location & $\begin{array}{c}\text { North Velebit } \\
\text { (̌̌uta Lokva) }\end{array}$ & $\begin{array}{c}\text { Senjsko bilo } \\
\text { (near Sv. Juraj) }\end{array}$ & $\begin{array}{c}\text { South Velebit } \\
\text { (near Seline) }\end{array}$ & $\begin{array}{c}\text { South Velebit } \\
\text { (near Muškovci) }\end{array}$ \\
\hline Ancient period & $320^{\circ} / 340^{\circ} \mathrm{N}$ & $65^{\circ} \mathrm{N}$ & $35^{\circ} \mathrm{N}$ & $6^{\circ} \mathrm{N}$ \\
\hline Recent period & $360^{\circ} \mathrm{N}$ & $307^{\circ} \mathrm{N}$ & $335^{\circ} \mathrm{N}$ & $3^{\circ} \mathrm{N}$ \\
\hline
\end{tabular}

\section{RIDGES ANALYSIS BY CRITERIA THE OF LENGTH}

The orientation of different ridge length categories is further threatened, in order to find out whether the difference in size implies the difference in the strain orientation. The results obtained by the ridges measurement were sorted following the length criteria. That means that the linear ridges, as well as approximate straight lines of curved ridges, represent one measured unit. It was a challenge to test whether small/short ridges and their curved parts show any differences in orientation compared to the big/long once. Were they developed or deformed under different stress influences? What kind of deformation reveals the present ridge morphology?

The analysis reveals two different kinds of orientations (Tab. 4). Small ridges and small parts of curved ridges show the $35^{\circ}$ orientation of maximum strain $\left(55^{\circ} \mathrm{N}\right)$. Those are $50 \mathrm{~m}$ long ridges and smaller once. Those between 50 and $225 \mathrm{~m}$ show the orientation $125^{\circ}\left(325^{\circ} \mathrm{N}\right)$ and those bigger then $250 \mathrm{~m} 135^{\circ}\left(315^{\circ} \mathrm{N}\right)$. The first orientation of small segments and small ridges may correspond to the recent direction of maximum stress. The other ones correspond to the old stress direction (NE-SW) which affected the mountain range during its formation. This initiates the reflections of two main different stress directions distinguishable from the ridges. The old one initiates with the NE movements of the Adriatic microplate and the recent one (NNW-SSE) is related to the NNW movement of the microplate (Blašković, 1998). Therefore small ridges represent parts of recent relief reshaping.

Tab. 4 Strain orientations obtained using the criteria of ridge length

Tab. 4. Orijentacija deformacije dobivena korištenjem kriterija dužine grebena

\begin{tabular}{|c|c|c|c|c|c|c|c|}
\hline $\begin{array}{c}\text { LENGTH in } \\
\mathrm{mm}\end{array}$ & $\begin{array}{c}\mathrm{N}^{\circ} \text { of } \\
\text { measurement }\end{array}$ & $\alpha \max$ & $\alpha \min$ & $180^{\circ}-\alpha \max$ & $90^{\circ}-\alpha \min$ & $\mathrm{a} / \mathrm{b}$ & RESULTS \\
\hline $0.5-1 ;$ & 1126 & $145^{\circ}$ & $55^{\circ}$ & $35^{\circ}$ & $35^{\circ}$ & 1.23 & $\mathbf{3 5}^{\circ}$ \\
\hline $1.5-4.5 ;$ & 11135 & $55^{\circ}$ & $145^{\circ}$ & 125 & 125 & 1.16 & $\mathbf{1 2 5}^{\circ}$ \\
\hline $5-7.5 ;$ & 4119 & $45^{\circ}$ & $135^{\circ}$ & $135^{\circ}$ & $135^{\circ}$ & 1.25 & $\mathbf{1 3 5}^{\circ}$ \\
\hline $8-10.5 ;$ & 1283 & $45^{\circ}$ & $135^{\circ}$ & $135^{\circ}$ & $135^{\circ}$ & 1.43 & $\mathbf{1 3 5}^{\circ}$ \\
\hline 11 and $>11 ;$ & 983 & $45^{\circ}$ & $135^{\circ}$ & $135^{\circ}$ & $135^{\circ}$ & 1.69 & $\mathbf{1 3 5}^{\circ}$ \\
\hline
\end{tabular}




\section{ANALYSIS OF SMALL HOMOGENIOUS ZONES}

Local differences are required from the zonal analysis, like the influence of faults and block differentiation. From those basic results (by zones) the strain directions will be drown. In the figures they will be represented by vectors do to the software limitations but they must be regarded as directions. Their variations throughout the area give the possibility to determine the strongly deformed zones.

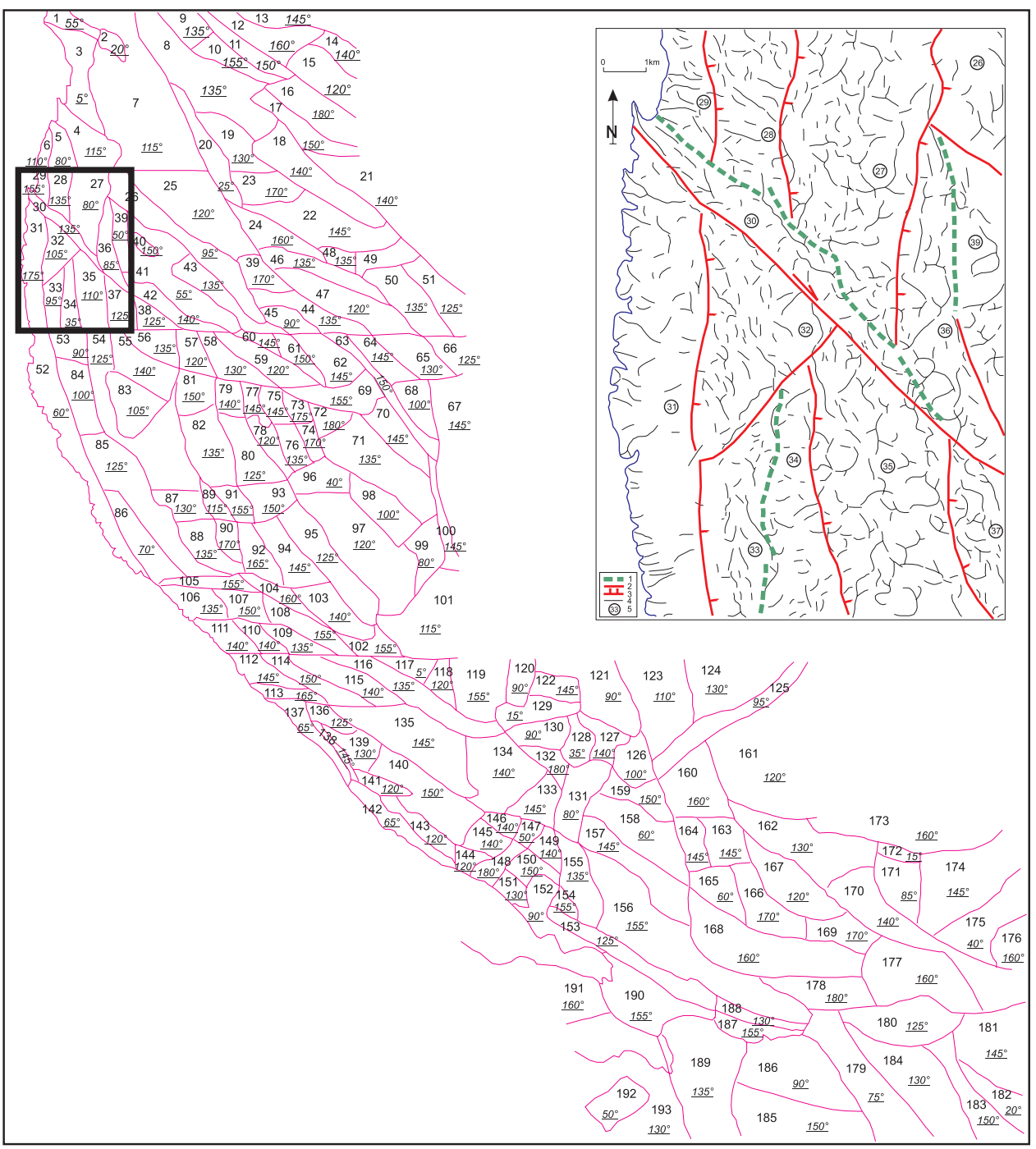

Fig. 5 Homogeneous ridge zones (193) on Velebit mountain range, (black quadrangle indicates the zoom for Fig. 5a)

Sl. 5. 193 zone homogenog pravca pružanja grebena na Velebitu (Sl. 5 a - uokvireno-uvećani prikaz jedne zone) 
As we have stated before the dominant orientation of ridges is around NW-SE. But there are also many little zones where the directions of ridges change. Those changes are of particular interest. In order to effectuate different kinds of a specific analysis, the studied area was divided into 193 little zones: 51 on the north, 60 on the central and 82 on the south Velebit. In this way the analysis of spatial variations was possible. They were defined as homogeneous as possible. It must be emphasised that faults were used as limits whenever it was possible (Fig. 5). Each of 193 zones was described with the main orientation, and the coefficient of ellipticity obtained by the Projection method. The biggest zones were later divided into smaller ones, maximally to five sub-zones depending on their initial size. In this way, the initial number of 193 zones has increased to 362 (Fig. 6 ). Those 362 values were used for the construction of strain directions in Fig. 7, as well as for the interpolation (Fig. 8).

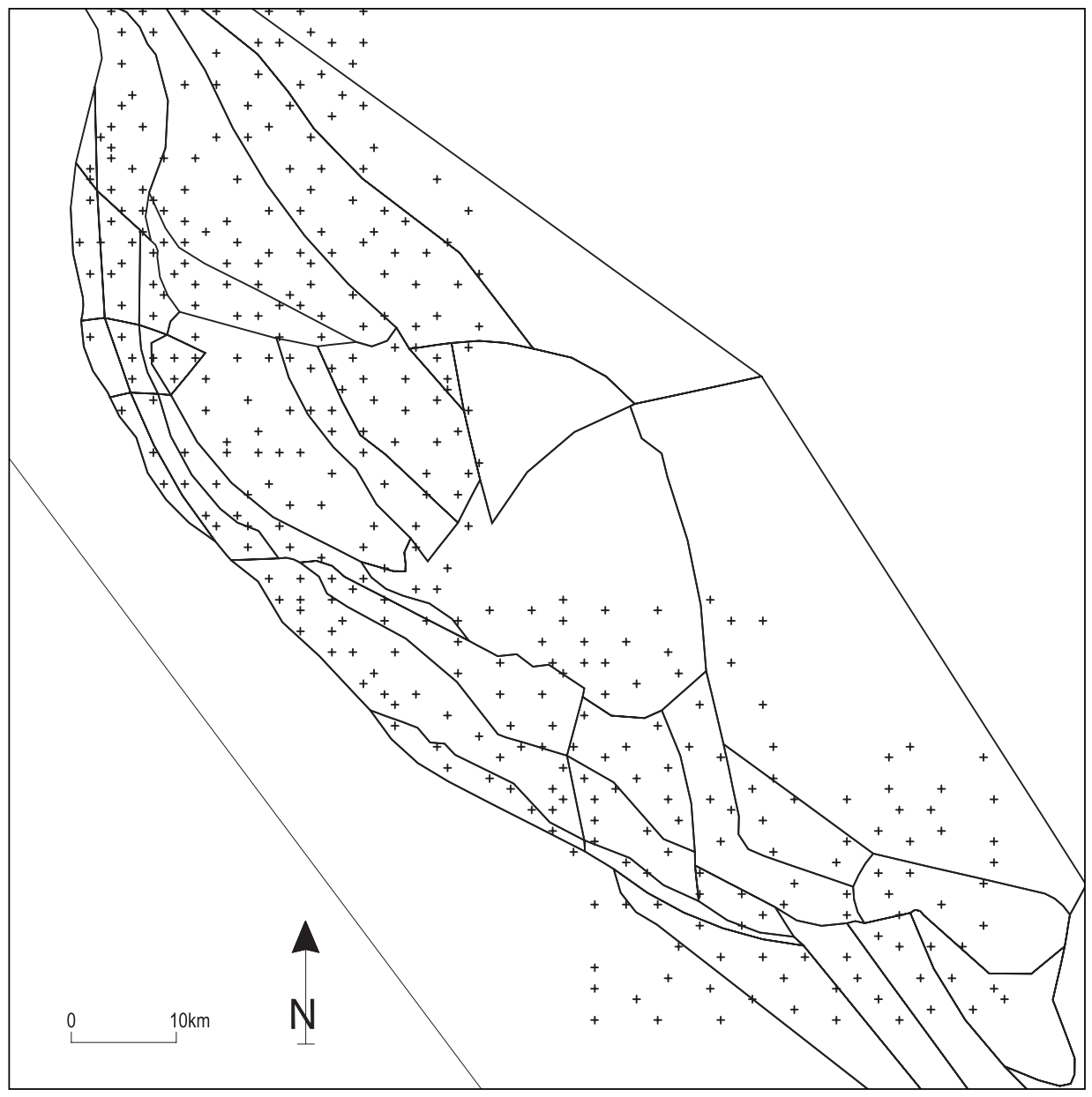

Fig. 6 Distribution of the strain measurement points on the fault-block model of Velebit Mountain created using main faults

Sl. 6. Točke mjerenja deformacije prikazane na modelu Velebita načinjenom korištenjem glavnih rasjeda 
Hrvatski geografski glasnik 69/2 (2007.)

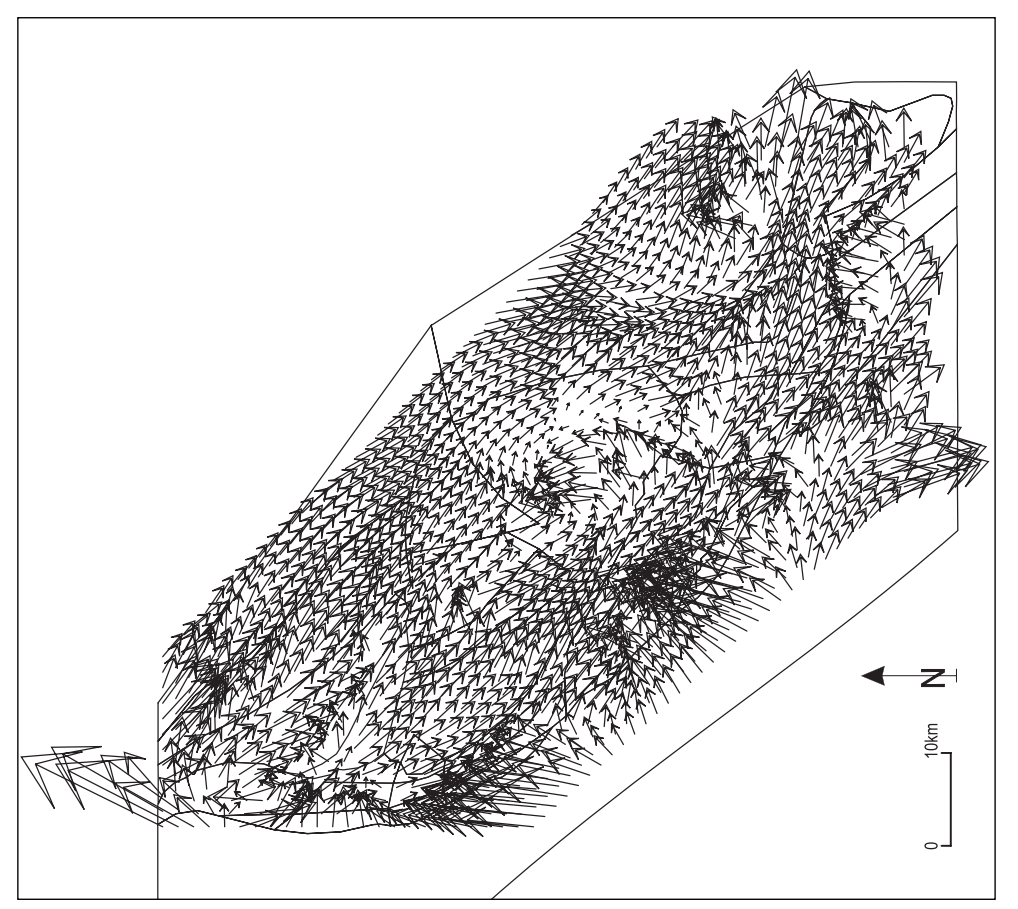

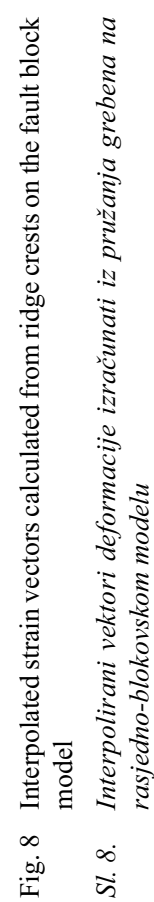

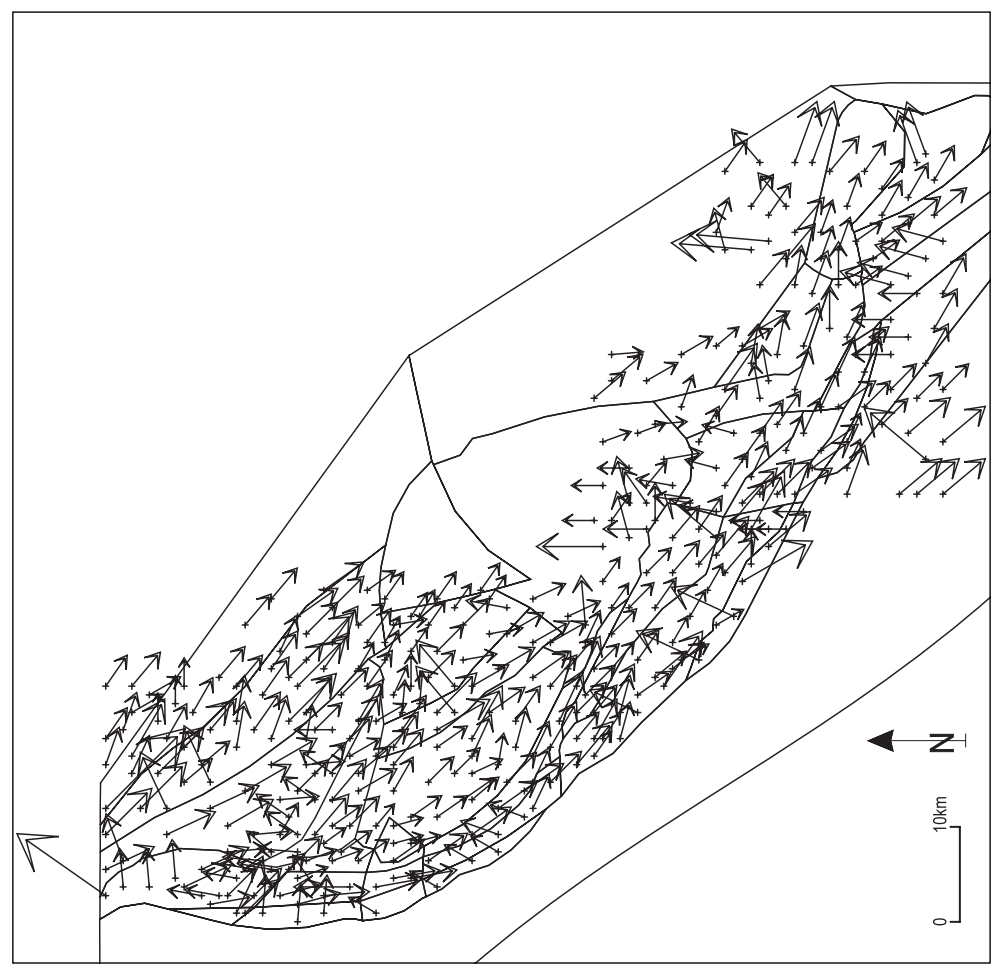

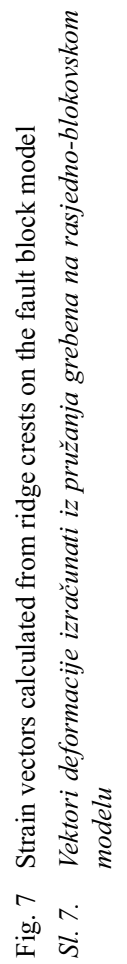


Correlating the map of principal directions with the structural map, we observe the concordance in directions of ridges and faults. On the north Velebit, many distinct blocks can be distinguished: the littoral slope of Senjsko bilo with the E-W ridge directions; the east part of Senjsko bilo, characterised by NE-SW small ridges, or the Melnice-Kuterevo mountainous tract which keeps the dinaridic orientation NW-SE. The polje of Gacka is easily distinguished by its E-W oriented ridges. The passage from Senjsko bilo to the north Velebit is also well noticeable in the landscape. Sveti Juraj fault is marked in the ridge directions which curve together with the fault from N-S toward NW-SE. It is also the stratigraphic contact between the Jurassic and the Cretaceous. Even if the polje of Krasno extends in the dinaridic direction, the ridges traverse the zone oriented N-S. The pull-apart basin of Lipovo polje (Prelogović et al. 1998.) has also its own particular ridge direction, more inclined to the west. It must be underlined that the pull-apart basins can be also distinguished due to their different ridge orientation. The last block of the north Velebit is the anticline of M. Rajinac with NE-SW orientation.

The contact zone of the north and central Velebit is well differentiated with the succession of ridges which follow the Lukovo and Bakovac fault. Comparing to the north Velebit, the central Velebit is represented by more gradual changes. Even though, there are two areas with completely different orientations. They are the narrow littoral zone with the NNE-SSW direction and the area in the central part of the block around Donje Pazarište - Otešica. Observing the central Velebit, it seems that a discontinuity in the ridge orientations began on the axis Karlobag - Cesarica - Otešica river. Till that point all ridge orientations can be bound in a hyperbolic curves indicating an anticlockwise rotation. But from the indicated axis, there is a change implying a transitional area toward the south Velebit. Eastward from Karlobag and Oštarije fault, ridges begin to curve progressively to the east. It appears as a fanlike opening whose east side is already the beginning of Lika field.

The south Velebit seems more homogeneous concerning the ridge orientation due to the distinct compressional stress regime. There is a general dinaridic orientation along the whole zone, becoming almost E-W on the extreme south Velebit. The contact with Lika field is marked by multitudinous changes. Very often ridges are oriented down the slope. Apart from that, there are two breaks in the relief of the littoral side: the small one near Lukovo fault and the other one following the Paklenica fault. Leaving the Velebit zone many changes appear, for example in the area of Bukovica and around the Novigrad sea.

\section{DEFORMATION RATE}

The large area of Senjsko bilo together with the Melnice - Kuterevo mountainous tract show the greatest ellipticity coefficient on the studied area. This is the consequence of the extensional stress regime which recently characterises the north Velebit and Senjsko bilo. Lukovo fault is the second area of the increased strain values, probably indicating its recent activity. The third such area is the upper zone of the Otešica river, between Bakovac village and Jasenovac hill, on the central Velebit (Fig. 9). Another area finds itself on the contact area between Brušane and Oštarije faults, that is on the passage from the central to the south Velebit. 


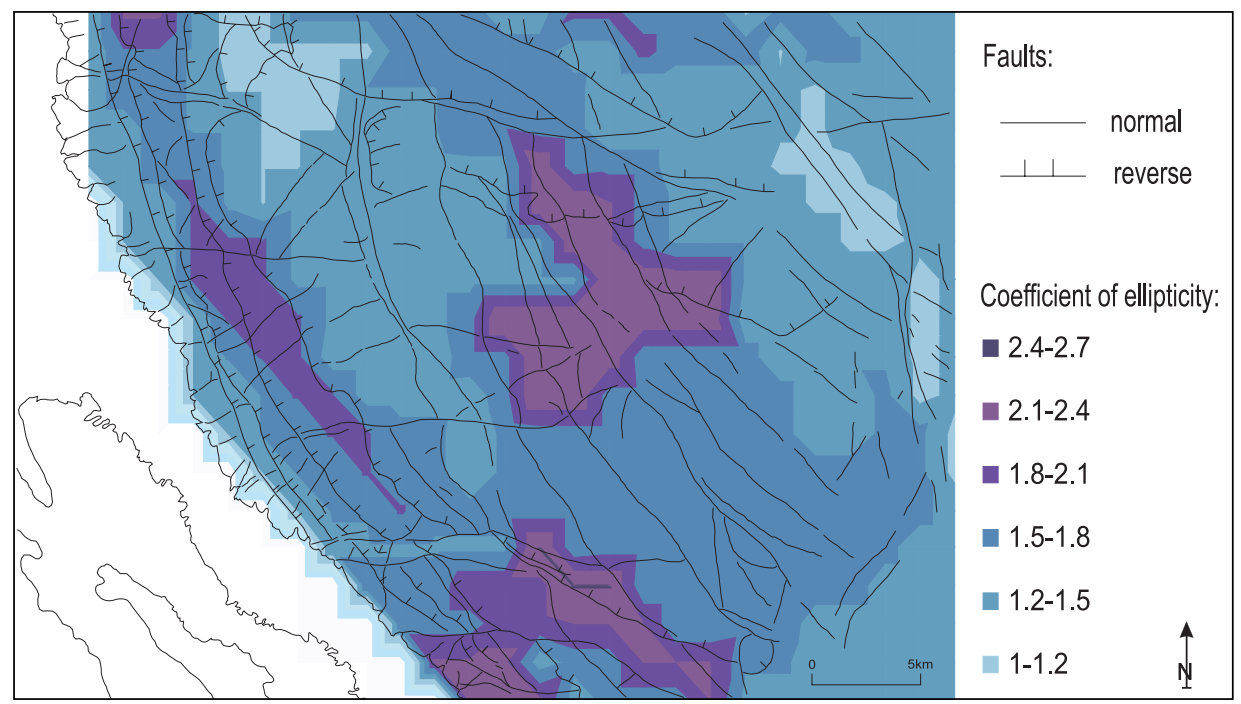

Fig. 9 Ellipticity coefficient map of the Central Velebit

Sl. 9. Koeficijent elipsoiditeta na srednjem Velebitu

In the south Velebit high values extend on small areas along the coast, around Lukovo and Paklenica faults. Along the N-S oriented faults on the Mogoric - Rok axis, there is one more area with the increased ellipticity coefficient. The extremely southern part of the Velebit fault zone shows some increased strain values as well. Most of the mentioned zones are characterised by recent fault activity.

\section{THE ANALYSE OF THE ANGLE OF RIDGE CRESTS BENDING}

As the short straight lines approximate the curvatures of the ridges, the angles between them have been successively calculated. The frequency diagram is presented in the Fig. 10. The most frequent are the classes of $25^{\circ}$ to $45^{\circ}$ angles indicating the change from the ancient to the recent stress direction as well as rotations and strike-slip movements.

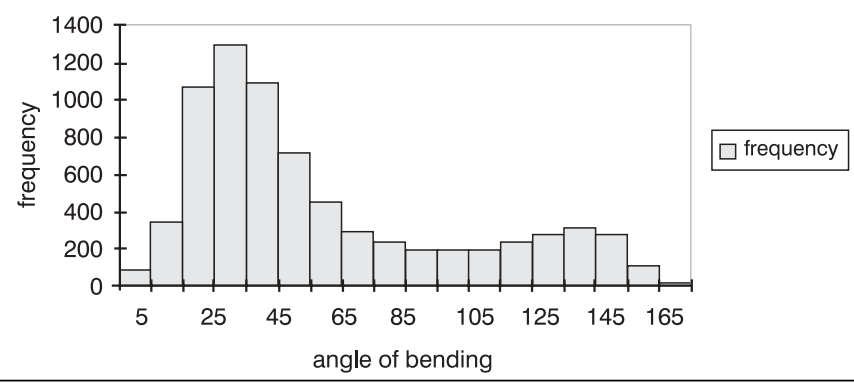

Fig. 10 Frequency of the angles of ridge crests bending on the Velebit mountain range

Sl. 10. Frekvencija kuta svijanja grebena na području Velebita 


\section{CONCLUSION}

It could be concluded that ridges reveal the cumulated effects of the superimposed tectonics where we can recognise the strong imprints of the ancient stress direction, before the change in the microplate motion, and also of the recent one. General ridge directions reveal the ancient tectonic relationships on the Velebit Mountain. But, a detailed analysis of ridge deformations allows one to detect the imprints of the recent tectonic influences on the original structural outline. The analysis of the principal strain directions and deformation rates reveal numerous zones, all of which point to the new recent stress orientation. Different maps systematically confirm the same areas of change.

The greatest masses of ridge crests are oriented $315^{\circ} \mathrm{N}$ which corresponds to the approximate ancient stress. Unlike that, the measurements of small reshaped ridges parts reflect the recent influences. The analysis confirms the change from the ancient NE towards the recent NNW stress direction, as find out by Prelogović et al. (1998). The angles of the ridge crests curvature reveal the most frequent angle classes from $25^{\circ}$ to $45^{\circ}$ indicating the recent influences on ridges crests deformation. The principal strain directions allow one to find out the variation of strain orientation throughout the area. The relative movements of rock masses and rotations are particularly well expressed.

The deformation rate allows one to differentiate areas which are strongly deformed like for example the north Velebit and Senjsko bilo areas which are marked by local extensional processes with the opening of many pull-apart basins. Therefore, ridges, which found themselves in an unfavourable condition, concerning the new stress, began to deform according to the recent tectonic properties. According to Cigrovski-Detelić, (1998) and Altiner (1999) it is the zone where the outer surface deformation is the most important one. The pull-apart basins can be well distinguished from the map of the principal strain direction because the ridge orientation often differs in comparison with that of the surrounding areas. The pull-apart basins indicate the structural origin of the numerous poljes on the studied area.

The obtained results are in accordance with the Mihljević's conclusions (Mihljević, 1995 ) that the present day orientation of the Velebit mountain range may be explained in terms of a shift. The assumed orientation of the Velebit fault route, as well as the entire Velebit structure, during the former tectonically active period ran NW-SE (Mihljević, 1995). With the change in stress during the latest tectonically active stage, the rotation of morphostructures started, followed by the gradual arc bending of the Velebit fault route, bordering the tectonic entities of Adriaticum and Dinaricum. The sinusoidal axes of the Velebit mountain ridges crest are therefore the consequence of the specific deformation kinematics that has developed during the latest, tectonically active stage, characterised by the counterclockwise rotation. This counterclockwise structure rotation on the area if External Dinarides have been already recorded by Prelogović (1989) and Marinčić and Matičec $(1990,1991)$. The kinematic mechanism causing this counterclockwise rotation is of vital significance for the entire present day relief of the Velebit Mountain. The retrograde rotation occurs along reverse fault paraclases of marginal or main geotectonic units, which have been abruptly inclined to the lithosphere depth (Mihljević, 1995). 
It is quite significant that the Velebit fault paraclase, running from SW towards NE gets abruptly perpendicular towards depths (Prelogović, 1981a, 1981b, 1995), so that the rotation is followed by the transport and stuffing of rock masses toward SW on the north Velebit and towards SE in the south what is generally reflected in the increase of the mountain ridge heights, in this very direction. As the rotation has been prograding, a differentiation between single morphostructural units of Velebit occurred, the result being: the north, central and south Velebit.

In this analysis ridges seems to be a good record for general studies of the past time tectonic activity. At the same time, they are the witness of the recent relief reshaping, whose footprints become an integrated part of their shape.

\section{REFERENCES}

Altiner, Y., 1999: Analytical surface deformation theory for detection of the Earth's crust movements, Springer Verlag, Berlin, Heidelberg, New York, 100 pp.

Anderson, H. and Jackson J., 1987: Active tectonics of the Adriatic region. Geophys. J. R. astr. Soc. 91, p. 937-983.

Belisario, F., Del Monte, M., Fredi, P., Funiciello, R., Lupia Palmieri, E., Salvini, F., 1997 : Azimutal analysis of stream orientations to define regional tectonic lines. Fourth International conference on geomorphology, 28.08-3.09.1997, Bologna, Supplementi di Geographia fisica e dinamica Quaternaria, Supplemento III, Abstractas, p. 74, Torino.

Birot, P., 1958: Morphologie Structurale. Presses Univers, Paris, 464 p.

Blašković, I., 1998: The two stages of structural Formation of the Coastal belt of the External Dinarides, Geol. Croat. 51/1, 75-89.

Bognar, A., 2006: The geomorphological evolution of Dinarides, Adria 2006 International Geological Congress on the Adriatic area, Field trip Guide, Ur. Menichetti, Marco; Mencucci, Daniela, Instituito di Science della Terra, Universita di Urbino, Urbino, Italija, 23-26.

Boni, P., Laureti, C., Ottone, C., Pellegrini, L., Rossetti, R., 1997: Morphotectonic influences on the drainage pattern in the North-western part of the Apennines (Northern Italy). Fourth International conference on geomorphology, 28.08-3.09.1997, Bologna, Supplementi di Geographia fisica e dinamica Quaternaria, Supplemento III, Abstractas, p.89, Torino.

Buonasorte, G., Pisa, S., Ciccacci, D., De Rita, D., Freudi, P., and Lupia Palmieri, P., 1991: Some relations between morphological characteristics and geological structure in the Vulsisni Volcanic Complex (Northern Italy). Z. Geomorph. N.F. Suppl.-Bd.82., p. 59-71.

Centamore, E., Ciccacci, S., Del Monte, M., Fredi, P., Palmieri Lupia, E., 1996: Morphological and morphometric approach to the study of the structural arrangement of northeastern Abruzzo (central Italy). Geomorphology 16, p.127-137.

Cigrovski-Detelić, B., 1988: The use of GPS measurements and geotectonic information in the analysis of the CRODYN geodynamic network. Unpublished PhD. Thesis. p. 145 University of Zagreb (in Croatian).

Coltorti, M., Farabollini, P., Gentili, B., Pambianchi, G., 1996: Geomorfological evidence for antiApennine faults in the Umbro-Marchean Apennines and in the peri-Adriatic basin, Italy. Geomorphology, 15 , p. 33-45. 
Faivre, S., 1999: Landforms and tectonics, Unpublished PhD thesis, University of Zagreb, Faculty of Science, Zagreb, Croatia \& Université Blaise Pascal Clermont II, Faculté des Lettres et Sciences Humaines, France \&. 364 pp.

Faivre, S. \& Reiffsteck, Ph., 1999a: Spatial distribution of dolines as an indicator of recent deformations on the Velebit mountain range. - Géomorphologie: Relief, Processus, Environnement, 2: 129-142.

Faivre, S. \& Reiffsteck, Ph., 1999b: Measuring strain and stress from sinkhole distribution, Example of the Velebit mountain range, Dinarides, Croatia. - In: Beck, B.F., Pettit, A.J., \& Herring, J.G., (Eds.): Proceedings of the Seventh Multidisciplinary Conference on sinkholes and the engineering and environmental impacts on karst: 25-30; Balkema, Rotterdam.

Faivre, S. \& Reiffsteck, Ph., 2002: From doline distribution to tectonic movements. Example of the Velebit mountain range. Croatia. - Acta carsologica, 31/3: 139-154.

Gerasimov, I.P., 1946: Experience with geomorphological interpretations of the general scheme of geological structure of URSS. Probl. Fizich. Geogr., 12, 89-115.

Herak, M., 1986: A new concept of geotectonics of the Dinarides. Prirodoslovna istraživanja 53, Acta geologica, vol.16, $\mathrm{N}^{\circ} 1$, p. $1-42$.

Marinčić, S., Matičec, D., 1990: Kinematika neotektosnkih deformacija na području srednjeg toka rijeke Neretve, Geol. Vjesnik, Vol 43. 53-58.

Marinčić, S., Matičec, D., 1991: Tektonika i kinematika deformacija na primjeru Istre, Geol. Vjesnik, 44, 257-268.

Mc Kenzie D., 1972: Acitve tectonics of the Mediterranean region. Goephys. J.R. Astron. Soc., 30, p. 109-185.

Mihljević, D., 1995: Relief reflection of structural reshaping during the recent tectonically active stage, in the north-western part of the outer Dinarides mountain range. Acta Geogr. Croatica, Vol. 30, p.5-16.

Morisawa, M. and Hack, J.T., 1985: Tectonic geomorphology. Allen and Unwin, Boston, 390 p.

Ollier, C.D., 1981: Tectonics and Landforms. Longman, London, 324 p.

Panozzo, R., 1984: Two-dimensional strain from the orientation of lines in plane. Journal of Structural Geology, Vol.6, No.1/2, p. 215-221.

Prelogović, E., Blašković, I., Cvijanović, D., Skoko, D. \& Aljinović, B., 1981a: Seizmotektonske značajke vinodolskog područja, Geološki vjesnik 33, 75-93.

Prelogović, E., Blašković, I., Cvijanović, D., Skoko, D. \& Aljinović, B., 1981b: Izbor metoda istraživanja seizmotektonskih odnosa na primjeru sjevernog Jadrana, Zbornik radova jubilarnog simpozijuma 20 godina LMGK, 3, 257-273, Beograd.

Prelogović, E., 1989: Neotektonski pokreti u području Sjevernog Velebita i dijela Like. Geol. vjesnik, 42, p. $133-147$.

Prelogović, E., 1995: Geological structure of Velebit mountain range. Paklenički zbornik Vol.1, Simpozij povodom 45. Godišnjice NP « Paklenica », Starigrad-Paklenica, p. 49-54. (in Croatian).

Prelogović, E., Kuk, V., Buljan, R., 1998: The structural fabric and seismotectonic activity of northern Velebit: Some new observations. Zbornik RGN fakulteta, Vol.10., 39-42.

Prelogović, E., Kuk, V., Buljan, R., Tomljenović, B. \& Skoko, D., 1999: Recent teconic movements and earthquakes in Croatia. - Proc. Geodynamics of the Alpe-Adria area by means of Terestrial and satellite methods, 255-262, Zagreb-Graz.

Prelogović, E., Pribičević, B., Ivković, Ž., Dragičević, I., Buljan, R. \& Tomljenović, B., 2004: Recent structural fabric of the Dinarides and tectonically active zones important for peroleum-geological exploration in Croatia, Nafta, Vol.55, 4, 155-161. Zagreb. 
Rebeiro-Hargrave, A., 1997: Large Scale Modelling of Drainage evolution in Tectonically Active Asymetric Intermontane Basins using Cellular Automata. Fourth International conference on geomorphology, 28.08-3.09.1997, Bologna, Supplementi di Geographia fisica e dinamica Quaternaria, Supplemento III, Abstractas, p.325, Torino.

Rovereto, G., 1923: Forme della Terra. Trattato di Geologia Morphologica. Hoeply, Torino, 2vols., 1187 p.

Twidle, C.R., 1971: Structural Landforms. The M.I.T. Press, London, 247 p.

\title{
SAŽETAK
}

\section{Analiza grebena gorskog uzvišenja Velebita}

\author{
Sanja Faivre
}

U današnjem reljefu uočavaju se strukture razvijene u prošlom, starijem tektonski aktivnom periodu i, naravno, one koje su nastale u recentnom razdoblju. Da bismo objasnili kako su nastali današnji reljefni oblici, važno je odrediti pravce pružanja prije nastalih struktura. U ranijim tektonskim i geomorfološkim studijama grebeni su često služili pri prepoznavanju horizontalnih pokreta na rasjedu. U ovom radu grebeni su analizirani po zonama, i to u globalnom smislu. Njihov oblik, pozicija i orijentacija su izučeni na cijelom istraživanom području. Kako se ključna promjena u morfogenezi Vanjskih Dinarida dogodila s promjenom kretanja jadranske mikroploče prema sjeveru i SSZ, utvrđen je utjecaj recentnog stresa na preoblikovanje ranije nastalih reljefnih oblika, u ovom slučaju grebena.

Da bismo izdvojili morfološke dokaze tektonskih pokreta uočene na grebenima, obavljena je detaljna analiza morfoloških aspekata na cijelom istraživanom prostoru. Svi tipovi i veličine grebena su uzeti u obzir te je tako načinjena osnovna baza podataka $\mathrm{s}$ 18603 mjerne točke. Obavljena je dvodimenzionalna analiza deformacije iz dominantne orijentacije grebena pomoću metode projekcija (Panozzo, 1984.). Analiza je zasnovana na tri kriterija: dužine, homogene zone te kutovi svijanja.

Najprije je analizirana orijentacija grebena prema kriteriju dužine da bismo saznali da li razlika u veličini uvjetuje i razliku u orijentaciji. Otkriveno je da su mali grebeni i zakrivljeni dijelovi svih grebena u skladu s recentnim pravcem regionalnog stresa. Suprotno tome, veliki grebeni upućuju na prethodnu tektonsku fazu (orijentirani su približno SZ-JI). U ovakvom tipu rekonstrukcije problem predstavlja drugačiji položaj Velebita u prethodnoj tektonskoj fazi kao i utjecaj sukcesivnih tektonskih faza. Stoga možemo jedino govoriti o aproksimaciji uvjeta starije tektonske faze.

Zonalna analiza omogućuje diferencijaciju glavnih strukturnih blokova i izdvajanje područja s različitom orijentacijom grebena. Proučavajući razlike u orijentaciji grebena, možemo uočiti i pull-apart bazene. Oni se uglavnom podudaraju sa zavalama polja u kršu, što upućuje na njihovu strukturnu uvjetovanost. 
Iz osnovne baze podataka konstruirane su karte glavnih orijentacija defomrmacije. Varijacije na istraživanom području upućuju na recentne pokrete i omogućuju određivanje zona pojačanih deformacija. Najveće deformacije zabilježene su na području sjevernog Velebita i Senjskog bila. Grebeni su uglavnom oblikovani u skladu s uvjetima starije tektonske faze, stoga su se u novoj fazi našli u vrlo nepovoljnom položaju i trpe velike deformacije.

Treći aspekt odnosi se na kut svijanja grebena, što je također posljedica utjecaja recentne tektonike na preoblikovanje grebena, tj. promjenu pravca maksimalne kompresije i rotacije struktura. Kutovi od $25^{\circ}-45^{\circ}$ pokazuju najveću frekvenciju. Na osnovi iznesenog može se zaključiti da je današnji položaj i oblik Velebita kao i grebena snažno utjecan rotacijom osi (simple shera) koji dovodi do skraćivanja i sigmoidalnog svijanja linearnih elemenata nepovoljno orijentiranih na glavni smjer stresa. Možemo zaključiti da je analiza orijentacije grebena omogućula prepoznavanje utjecaja različitih pravaca generalnog stresa na području Velebita.

Received (Primljeno): 2007 - 04 - 16

Accepted (Prihvaćeno): 2007 - $05-18$

Dr.sc. Sanja Faivre, assistant professor, Department of Geography

Faculty of Science, Univesity of Zagreb, Marulićev $\operatorname{trg} 19 /$ II

10000 Zagreb, Croatia

e-mail: sfaivre@geog.pmf.hr 